\title{
The Evolution of Qur'anic Interpretation in the First Three Centuries of Islam
}

\author{
Yusuf Olawale Owa-Onire Uthman \\ yusuf.uthman@ibnhaldun.edu.tr.
}

Faculty of Islamic Studies, Department of Tafsir, Ibn Haldun University, Turkey

\begin{abstract}
This study deals with the historical development of the exegesis of the Qur'an from the first to the end of the third century of Islam. It explains the events that elevated tafsir in this era. During these periods, the study of tafsir has gradually gained methodical activity; the Prophet's teachings to the Companions was the highest development towards the evolution of Quranic exegesis. However, the Prophet taught them the Qur'an and solved their problem concerning the understanding of the Quran. The paper highlights the striving of the companions in devoting their lives to learning the Qur'anic Tafsir. Therefore, the mainstream exegesis is traced to the Prophet and his companions. The research also elucidates the exegetical position of the successors after the companions to extend the era of the genesis of tafsir to the third century. Lastly, the study listed the scholarly roles played by these golden generations of Islam to achieve the knowledge of the authentic meaning of the Qur'an and its connotations. However, current scholars are highly advised to employ academic efforts on the study of Qur'anic exegesis in line with the direction of these three Muslim's generations.

This is an open-access article under the CC-BY-SA license.
\end{abstract}

\author{
Article history \\ Received 2020-07-15 \\ Revised 2021-08-25 \\ Accepted 2021-10-07 \\ Keywords \\ Islam \\ Tafsir Development \\ First Century \\ Second Century \\ Third Century
}

\section{Introduction}

The Quranic exegesis is nowhere to be without Quranic revelation. Meanwhile, every scripture from Allah is sent to the Prophet to guide humankind. To prove this context, Allah has stated in the Qur'an: "all humanity were once one single community; then they began to differ, after which God raised the prophets as heralds of glad tidings and a warner, and through them bestowed revelation from on high, setting forth the truth, so that it might decide between people about all on which they had come to hold divergent views (Q2: 213)." In tafsir al-Jalalayn, the scripture is known as a revelation: and He revealed with them the scripture, meaning, the Books, with the truth (bil-haqqi, 'with the truth', is semantically connected to anzala, 'to reveal') (al-Mahli, 2001: 44). 
In addition, it can refer to what Allah has revealed to His Prophet as a pearl of wisdom. This opinion is derived from the word of Imam Sha'fi, in his translation to this verse: "even as We have sent unto you a messenger from among you, who reciteth unto you Our revelations and causeth you to grow, and teacheth you the scripture and wisdom, and teacheth you that which ye knew not" (Q2: 151). Al-Imam Sha'fi (d. 204/820) expounds that the book mentioned by Allah was the Qur'an, while wisdom stands for the prophetic tradition. So the understanding is that the sunnah and Allah have commanded humankind to embrace and follow its teaching to gain an everlasting reward: al-jannat (Sha'fi Abu 'Abdullah, 2006: 241). Therefore in this part of this research, it will be a good idea to draw the road map to the destination. We have a short explanation about the word revelation, then the definition of exegesis will be considered.

The linguistic meaning of revelation is to be intimate or to have a conversation with somebody by heart. The word revelation (wahy) is probably used in various places to express several meanings like inspiring, sending a message to the heart, and communicating Allah says: "We inserted this into the mind of Musa's mother".(Q:28:7). Also as assignment or duty upon both living and nonliving things: And thy Allah instructed the Bee to build its cells in the hills. (Q16:68) And He assigned to each heaven its duty and command. (Q41:12) To discourse taciturnly: Then (Zakariyya) came out from the shrine and told them by signs to give glory to their Lord in the morning and evening. (Q19:11). All the mentioned verses are based on the meaning of the word revelation (wahy) in Arabic (Khanam, 2001: 64-65).

Moreover, the conventional use of the word revelation is in the sense of spiritual conversation and guidance from Allah for his creation. This guidance is brought by the Prophets, who are in state of receiving the word from Allah through one of the means mentioned in the coming categorization: 1) insight (Wahi Al Qalbi) for instance, in a dream Syedna Ibrahim (a.s. ) receives guidance in a vision, while asleep, to sacrifice (his son), 2) conversation in hidden (Kalaam i-Ilahi) Allah spoke to Syedna Musa (a.s.) behind the veil, and 3) messages sent through an angel (Wahi Malaki), Allah sent angel Jibril (a.s.) to the beloved Prophet Muhammad (saw) to reveal His message.

These above-listed categories of the meaning of revelations were explained in the glorious book its-self Allah states: "And every man does upon not have the faculty that Allah should speak to him (directly) except by Revelation (He bestows some the holy status of Prophethood), or (should speak) from behind a veil (as He spoke to Musa on Mount Tur of Sinai), or by sending some angel as a messenger to reveal with His permission what Allah may will. (In any case, the medium and large mediation of the communication of Allah's Word for humankind is none but the Prophet and the Messenger.) Surely, He is Most High, Most Wise". (Q:42:51). This is the field meaning of the word revelation (Von Denffer, 2015: 7-8). 
Lastly, It was said that there were among the Prophets of God who heard the sound of revelation and were able to understand it, and there were also among the Prophets who revelation was revealed to through the dream. Indeed, the angel Gabriel visits Prophet Muhammad (May peace be upon him) like how a friend calls his friend in nice cloth with evergreen legs (Abu alHasan, 2002: 775).

In all probability, the Qur'an is a composed of verbal revelations that were descended to Prophet Muhammad, during the first century of Islam at the moment of twenty-three years at Makkah (610-622) and Madinah (622-632). The verses that was revealed first are verses 1-5 of Chapter 96 was the last chapter revealed to the Prophet according to Bukhari (d. 256/870) and Muslim's (d. 262/875) reports from the wife of the Prophet Aysha (d. 59/678) (R.A) in al-itqon of Suyuti (d. 2081/1505) and also the last verse revealed to the Prophet was the verse 281 of chapter 2 of the Quran in the same book (al-Jalal as-Suyuti, 2010: 71-72). Also, according to As-Sufyan alThawri (d.161/777), Ibn 'Abbas (d. 68/687) reported the fact that the last verse revealed in the Qur'an was the verse 281 of Surah al-Bakara, which is chapter two of the glorious Qur'an (AlThawri, 1983: 73).

In addition, following the cognizance about the revelation in the subject of tafsir and its evolution, the definition of the word tafsir in linguistic and technical meaning should be provided. Shortly the word tafsir (exegesis) is a common Arabic word from fassara, yufassiru, tafsir. Zarkashi (d. 794/1392) in al-Itqon stated that tafsir is known as a scientific study of the Qur'an that was revealed to Prophet Muhammad (peace be upon him) by explaining its meaning and deriving all its aggregate classical rules (al-Jalal as-Suyuti, 2010: 461).

\section{Discussion}

\section{Tafsir in the First Century of Islam}

Generally, tafsir is noted since the lifetime of the Prophet; in the first century, the exegesis of the Quran is a constance task upon the prophet-hood through the commandment from Allah to his messenger (peace be upon him). It can be traced when God instructed the Prophet to explain His word to his companions in particular and to the nation as a whole. Allah states that "and We have also revealed the $d z i k r$ (reminder) to you, so that you may clearly explain to men what was revealed to them, so that perhaps they may examine themselves" (Q16:44).

Ibn Kathir (d. 773/1372) said that "because you know the meaning of what is revealed to you, and you are very keen about it and follow it, and because we know that you are the best of creation and the leader of the sons of Adam, you will illustrate to them in particular what is mentioned in brief, and you will explain to them what they cannot understand." "And that they may give thought" means "so that they may conceptualize themselves and be guided, and thus achieve salvation in both 
the kingdom [The world and the Afterlife] (Ibn Katheer, 1999: 573). However, this verse's like is noted in the noble book of Allah, where the Dhikr is mentioned to refer to al-Qur'an. Almighty Allah says: [Q15:9] “Lo! We, even we, reveal the Reminder, and lo! We verily are its Guardian”. Exegetical expression to this particular verse according to Qatadah (d. 117/735), is the special protection of Allah for the Qur'an against any Satanic corruption; also He protected it against any bad interruptions (As-San'ani, 1998: 251). In this noble verse, it is well understood that the Dhikr is Quran which the Prophet is in charge of teaching it to the Muslims in this period.

Utterly the prophetic tradition is suited for referring to the field of Quranic exegesis because of his position as a messenger of God. They have the bountiful opportunity of receiving the sacred book (Quran). Allah says in His word Q59:7. Anything the Messenger has presented to you take it, and what he has forbidden you to abstain from it. "The Islamic scholars agree that the Prophet himself vindicated this point to Muslim Ummah that there are certain works of supplication which were not declared in the Qur'an.

Meanwhile, the tradition of Muhammad (peace be upon him) will be in the position to explain or clarify what was not mentioned clearly in the Quran and that was the meaning deriving from the forthcoming Hadith: " Take your rituals from me" he also said, "pray as you have seen me pray" (al-Qurtabi, 1997: 37). In the cause of the (Jihad/striving) Allah said in the: [Q47:35] "So do not falter and cry out for peace when ye (will be) the uppermost, and Allah is with you, and He will not grudge (the reward of) your actions" and He also said: [Q4:75] How should ye not fight for the cause of Allah and of the feeble among men and of the women and the children who are crying: Our Lord! Bring us forth from out this town of which the people are oppressors! Oh, give us from thy presence some protecting friend! Oh, give us from Thy presence some defender!"

These two verses' meaning was explained by the Prophetic tradition (Sunnah). Here is the word of the Prophet reported by Imam Bukhari (d. 256/870): Allah's Apostle said, "There is no Hijra (i.e., migration) (from Mecca to Medina) after the Conquest (of Mecca), but Jihad and good intention remain; and if you are called (by the Muslim ruler) for fighting, go forth immediately." The Hadith is able to explain these verses (al-Hawri al-Baghdadi, 1997: 201).

Nevertheless, the prophetic exegesis is based on the following technical expression. First, explaining the worshiping matters: like his explanation toward the ayah: "And ascertain the prayer and pay the Zakat" (Q2:42). The Prophet's word explains this: Learn your rites from me and pray as you saw me praying. Second, clarification of the confusing words: this kind of interpretation is made when the Prophet explains the meaning of the verse (Q2:186). Allah states that "eat and drink until the white thread of dawn is cleared to you from the black thread of night." Udai b. Hatim narrated that he asked the Prophet about this verse and whether it means the black and white thread? But he answered (No, it is the darkness of the night and the lightness of the 
day).

Third, cpecifying the genetic issues. This type occurs in the (Q6:82) the Lord (saw) said: "Those people that believed in Allah and did not combine their faith with a grievance." When this verse was revealed to the Prophet was so scared and said who among us did not attribute to the common injustice! The Prophet now clarify the significant meaning of the verse to them with another verse of the Quran that the injustice meaning in verse is associating something with Allah (al-Shirk) this is understandable in his word (peace be upon him)." No, is not as you said, did you not hear what Lukman (as) said to his son: 0 son, do not associate anything with Allah is a huge injustice" (Q31:13) this narration is from authorities like Abu Bakr al-Siddiq (d. 13/634), Umar (d. 24/644), Abay b. Kaab (d. 29/649), Salman (d.32/652), Hudhaifa (d.656), Ibn Abbas (d. 68/687), Ibn Umar (d. 693), Abu Abdul Rahman al-Salami (d. 412/1021), Mujahid (d. 104/722), Ikrimah (d. 105/723), al-Nakhai' (d. 75/694), Al-Dahhak(d. 102/720), Qatada (d. 117/735) and al-Sad(d. 55/674) (Ibn Kathir, 1999: 290).

Fourht, restriction on the unrestricted. The example of this is the word Allah: (As for the male and female that engages in thief activities, amputate their hands) Q5:38. The Prophet interpreted the verse to mean cutting off the right hand only, this is known when they took a thief to him, and he ordered that they should cut off his right hand (Abdul Raof, 2010: 12-15).

Moreover, in the first century, we also have the exegetes among the companions, who happen to be the great students of the Prophet. In the first line of counting their names, the four guided caliph; Thus, many narrations of exegesis are not attributed to some of them due to the preoccupied with the caliphate activities, and there were many scholars of Quranic interpretation among them, so there was no need to transmit their self since their interpretation is based on what they understood from their dear teacher the Prophet.

These companions have much priority in commitment to serve Allah upon the commandment by the Prophet through the order from their creator Almighty Allah. Thus, they are known as the best generation of Islam Allah said in the [Q35:32] "Then we gave the scripture as an inheritance to those we elected of our bondmen. But of them are some who wrong themselves and of them are some who are lukewarm, and of them are some who outstrip (others) through good deeds, by Allah's leave. That is a great favor!"

The exegete, Yahya bn Sallam (d. 200/815) reports al-Hassan bn Dinar from al-Hassan who said "those that outstrip (others) with doing good deeds are the companions of the Prophet (Peace be upon him), but those who are lukewarm are the seeker of the footstep of the companion, and then follow it, while those that wrong themselves are a hypocrite who is not in the mentioned categories (Al-Ifriqi, 2004: 790). There were famous companions with the many transmissions of exegesis of the Qur'an; their name and short fictions are as follows. First is Ali b. Abi Talib. He is a 
cousin of Prophet Muhammad; he was brought up from the Prophet home, and he is well known for his brilliant naturally, he always told people to ask him about the Qur'an and its interpretation; because he was very knowledgeable about its revelation, for this reasons exegete among the companions referred to him due to the trust they have in him. The second is 'Abdullah b Mas'ud (d. 33/653). Ibn Ghafil al-Hudhali, Son of umm 'Abdul, he was also close to the messenger and he was influenced by his guidance to the way Allah, he was the most famous interpreter among the companions. The third is 'Ubay b. Ka'b (d. 29/649): he is from the tribe of Najār, He embraced Islam in the early stage he witness the of 'Akaba, and he was a famous memorizer of the Quran, and he has the best recitation.

The forth is Zayd b. Thābit (d. 40/660). His name is Zayd b. al-Duhāk b. Zayd b. Lawthān, his was attributed to the tribe of Mālik b. Najār is a scribe and one of the jurists, and he is also known as a sound Hafiz who was famous for an accurate recitation of the Qur'an; he was among the committee whenever they are gathering the Scripture of the Qur'an even he was the president of the set during the period of 'Uthman b. 'Affān. (More blessings of Allah be upon him). The fifth is 'Abdullah b. 'Abbas (d. 68/687). He was a cousin to the Messenger of Allah (saw), and he was born three years before the emigration, and what made him a great man is that; he is the son of Prophet maternal aunt, and the Messenger of Allah prayed for him on wisdom and knowledge of jurisprudence in the Islamic religion and was called the learned man of the Islamic nation because of his skill and his huge knowledge in jurisprudence and exegesis of Qur'an.

The last is Abu Musa al- Ash'ari (d. 42/662), and Abdullah b. Zubayr (d. 73/692). These are the most famous companions in the field of Quranic exegesis in the first century of Islam (blessings of Allah be upon every one of them) (al-Tabari, 2013: 15-19). Some scholars like as-Suyuti added three companions to this list, like Anas b. Malik (d. 94/712), Abu Hurayra, 'Abdullah b. 'Umar (d. 74/693), Jabir b. 'Abdullah (d.78/697), Abu Musa al- Ash'ari. Actually, compared to the firstmentioned list, their transmission of exegesis is not many.

Lastly, there are four delighted schools of exegesis established by these great students of Prophet (companions), to spread the knowledge of Tafsir: School of interpretation in Makkah by 'Abdullah b. 'Abbas (d. 68/687), the school of Medinah by Ubay b. Ka'b (d.29/649), school of Kufah by 'Abdullah b Mas'ud (d. 33/653) and the school of exegesis in Basra that was established by alHassan al-Basri (d. 110/728) (Abdul Raof, 2010: 149-150). The product of the schools were the prominence successors who learned the exegesis from the companions, the successors are listed as follows: In Makkah school, Ibn Abbas taught Sa'eed b. Zubair (d. 95/714), Mujahid b. Jabr (d. 104/723), 'Ikrimah (d. 104/723), Taawuz (d. 106/725), and 'Ataa b. Rabaah (d. 114/733) they are all famous in the works of Quranic exegesis. Also, in the school of Madinah, the students of 'Ubay b. Ka'b are Abu al-'Aliyah (d. 95/714), Muhammad b. Ka'b al-Quradi (d. 118/737) and Zayd b. 
Aslam is reputable and known in the school of Medinah at that particular time. In the school of Kufah students of 'Abdullah b. Masu'd was famous for his heritage in exegesis, and they are Alqamah b. Qays (d. 61/681), Masruq (d. 63/681) and al-Aswad b. Yazeed (d. 74/689). Some successors were also renowned in the knowledge of tafsir, like Aamir ash-Sha'bi (d. 109/728), alHassan al-Basri (d. 110/729), and Qatada as-Sadusi (d. 177/794) (Yasir Qadhi, 1999: 297). They are all scholars in this credible knowledge section, particularly during the first century of Islam.

\section{Evolution of Qur'anic Exegesis in the Second Century of Islam}

In this century, the Quranic exegesis has passed through a new dimension under the supervision of the successors, while the exegesis moved to its first recording phase. Thus, in the first century, the prophetic interpretation is the primary source of authentic exegesis. Meanwhile, the companions based their Quranic interpretation on the prophetic legacy and their self-opinion linked to transmission from Prophet Muhammad (saw) in this particular era. According to Abu Mansur al-Maturidi (d. 333/945). The interpretation until this time (second century) did not take a recorded form and was not singled out for notation, instead it was written as one of the various sections of Hadith, in which they gathered what was narrated from the Prophet (peace be upon him) and from the Companions and the followers.

However, Maturidi then perhaps mentioned that the interpretation separated from the Hadith, and it was singled out with extraordinary compositions. The first exegesis that was known to us is the scripture of tafsir that Ali bin Abi Talha (d.143/760) narrated on the authority of Ibn Abbas. After that, he found parts that were written down in the exegesis in particular, such as that part attributed to Abu Ruq, and those three parts that Muhammad bin Thowr (d. 190/806) narrates on the authority of Ibn Juraij (d. 150/768) (al-Maturidi, 2005: 264). Thus, in this particular era, the tafsir started its recorded journey and also gained the starting point of separation from the science of Hadith. So, simultaneously as in the second century of Islam the successors (students of the companions) used the teachings of their masters and their self-effort towards the development of the interpretation of the Quran (Nabia, 2002: 449-462).

More so, the guidance from Allah on this great generation cannot be disputed. Neither His safeguard upon His revelation can be questioned in any case? Absolutely No is the answer to this question why; because Allah has described this particular set of people living this period of time in His word Q2:110 “You are the best nation produced [as an example] for humankind. You enjoin what is right and forbid wrong and believe in Allāh. If only the People of the Scripture had believed, it would have been better for them; among them are believers, but most are definitely disobedient). Evidence of Muslims being the best nation was quoted by az-Zujaj (d. 310/922) in his exegesis to the Hadith of the Prophet Muhammad (Peace be upon him): "The people of my generation are the best, then those who follow them, and then whose who follow the latter." Az- 
Zujaj disclosed that the first best generation is the companions who lived in the Prophet's era; those that follow them are the successors after them, then the generation of those that learn the Din (Islam) from the successors. However, the word generation can stand for the Muslim community as a whole, so the people (Muslims) of the community will be known to be the generation. According to Ibn Kethir this verse explains the Muslim generation's quality characteristics. That means they were appointed to encourage proper things and forbid unlawful acts while believing in Allah (Ibn Kathir, 1999: 93).

Historically, the Quranic exegesis was exposed to the stage of recording its materials after learning it by heart that occurred in the first century. In the famous Islamic book at-Tafsir wa alMufassirun al-Dhahabi argued that the second century of Islam brought forth the writings of tafsir and it was known to begin at the end of the Umayyads regime (d.41/661-132/749), which is the starting of the tenure of 'Abbasid's empire (132/749) and exist till today. Before this time, the Prophet transmitted exegesis by companions, and between themselves, the successors also passed by this road of the message (al-Dahabi, 2000: 104). Besides, in the second century, the exegesis was collected along with the Hadith; some Ayahs were combined with the Hadith and transmitted by the scholars of Hadith like Yazid b. Harun al-Salami (d.117/735), Shu'bah b. al-Hajjaj (d.160/776), Sufyan al-Thawri (d.161/777), Waki' b. al-Jarrah (d.197/812), Sufyan b. 'Uyainah (d.198/813), Ruh b. 'Ubadah al-Basri (d.205/820), 'Abd al-Razzaq al-San'ani (d.211/826), Adam b. Abi Iyas (d.220/835) and 'Abd b. Humaid (d.249/863). Imam as-Suyuti (d.911/1506) in alItqon mentioned this opinion (as-Suyuti, 2010: 489).

Furthermore, the Quranic exegesis gained its independence within a short period from the margin it with Hadith. This movement can be called the total recording phase of the exegesis of the Quran when many Islamic disciplines, like Islamic jurisprudence and theology, were technically derived and gained their maturities from Quranic exegesis understanding (Rauof, 2010: 161). There are many exegetes for recording some surahs and ayah; they are famous for this task to date, they are as follows: al-Dahhak b. Muzahim al-Balkhi (d.105/723), Muqatil b. Sulaiman al-Balkhi (d.150/767), 'Abd al-Malik b. 'Abd al- 'Aziz b. Juraij (d.80-150/699-767), Sufiyan b. Sa 'id b. Masruq al-Thawri (d.161/777), Yahya b. Salam (d.124-200/741-815), Abu Zakariya 'Abdullah al-Farra' (d.207/822), Abu Bakr 'Abd al-Razzaq al-San'ani (d.211/826), Ibn Majah (d.273/886), Ibn Jarir al-Tabari (d.310/922), Abu Bakr b. al-Mundhir al-Naisaburi (d.318/930), 'Abd al-Rahman b. Abi Hatim (d.327/938), Abu al-Shaikh b. Habban (d.369/979), alHakim (d.405/1014) and Abu Bakr b. Mirdawaih (d.410/1019). Generally, these mentioned exegetes focused on the prophetic narration and the companion transmission in their Quranic interpretation. Moreover, the narration from the companion's student is also a choice to them; in short, the notion of their explanation can be called the revelational exegesis (al-Tafsir bil-ma'thur). 
According to some opinions, the first exegete who collected and interpreted the Quran from the beginning to the end was: Muqâtil b. Sulaiman (d. 150/767). Some scholars said Ali b. Abi Talha (d. 143/760) because of his book: Saifeh Ali b. Abi Talha in Quranic interpretation, while some of them said is, Abu Zakariya Yahya b. Ziyad al-Ferrâ (d. 207/822) and his book is "Mâni'al-Quran". Also, Ibn 'Ashûr (d.1393/1973) said Abdul Malik b. Juraij (d. 150/767) was the first that recorded tafsir. However, many notable data reviews that Muqâtil b. As mentioned above, Sulaiman is the first person who interpreted the Quran from beginning to end. Whereas all these mentioned exegesis books were based on explaining the ambiguous, or interpreting the Quran linguistically, or deriving the occasion of the Quran, they presented different ways of reading the Quran (Doğan, 2019: 47-66).

Finally, it is a good idea to study a work of an exegete in this second century of Islam. In this regard, the book of al-Farra' (Ma'ani al-Quran was written following the demand from one of his students 'Umar b. Bakir during the tenor of Al-Hasan ibn Sahl; who was an Abbasid official and controller of Iraq for Khalifah al-Ma'mun during the Fourth Fitna, the student of al-Farra' demanded writing the book with the fear of not knowing the meaning of verse of Qur'an if the governor accidentally asked him about it. This request was granted from the teacher and al-Farra' gathered them in a mosque, he asked one of them to read from Surah al-Fatih, and he interpreted it till the end of the book. Abu al-Abbas states: Nobody has done exactly his work, and I do not think anyone will overcome his spent effort concerning the Quranic exegesis (al-Farra', 2014: 13).

\section{Evolution of Qur'anic Exegesis in the Third Century of Islam}

In this part of the study, we shall form an investigation of the development of Quranic interpretation in the third century. However, there are difficulties in finding the previous works in tafsir that confines the details in textual context. This is experienced throughout this study, especially in this last part of the third century. Notwithstanding, the tafsir has gained advancement in its genesis due to its many semantic explanations in this period. The spreading of Islam has also contributed a vital role to the development of exegesis in this century of Islam.

The quotations from pre-Islamic Arabic poetry and Arabic linguistics are added to their works in this century. Thus, the spreading of Islam has encouraged this kind of grammatical development in the field of tafsir. To achieve more understanding about the context of the Qur'anic meanings, the exegetes of the third century of Islam developed their exegesis skills with these quotations in various disciplines of Islamic knowledge. Among the exegetes that focus on this mentioned grammatical analysis methodology are Abu 'Ubaidah Ma'amar b. al-Muthana (d. 210/826), in his book Majaz al-Quran, al-Farra' (d. 207/823) in his work called Maa'ni al-Quran, and al-Akhfash in his book Maa'ni al-Quran (Ibn Jma'ah, 2010), Muhammad b. Mustanir al-Basri known as Qatrab (d. 211/827) he is Mu'tazili and he also has his work called Ma'ani al-Quran, Abu 'Ubaid al-Qasim 
b. Salam al-Hiwari (d. 224/839)) in his work Ma'ani al-Quran, according to ad-Dahabi, he is the first scholar to write a books about the linguistic meaning of Quran and his work was Ma'ani alQuran, followed by Qatrab, al-Akhfash, and others. Then this current list we still have the work of Abu Muhammad Abd-Allah b. Muslim b. Qutayba al-Dinawari (d. 276/890); Gharib al-Quran and Ta'wil Mushkil al-Quran, al-Hussain b. al-Fadil b. 'Umair al-Bajali (d. 282/896) his work in Arabic contest is also Ma'ani al-Quran, ad-Dahabi and other scholars testify to his Tafsir scholarship, Ismail b. Ishaq b. Hammad b. Zayd al-Azdi al-jahadami (d. 282/896) his work is available with the name Ma'ani al-Quran, Abu Ishaq az-Zujaj (d. 311/924) in Ma'ani al-Quran wa I'irabuhu; "the example is cleared in his work" (Az-Zujaj, 1988: 365), and his work is the greatest among the previous grammatical exegesis of Arabic literature, Abu Ja'far Ahamad b. Muhammad b. Ismail anNahas (d. 338) his work is named I'irab al-Quran wa Ma'ani al-Quran, and the last exegete in this list is Muhammad b. al-Karaji al-Qasab (d. 360/971) his work Nakatu al-Quran ad-Dalah 'a'la alBayan (al-Mutayri, 2021).

Similarly, the Islamic theological reflection in tafsir, scholars of this great field also contributed to the evolution of Quranic exegesis in this particular period. However, Islamic sects somehow have a reflection in the formation of tafsir in this era of its development. This sect of groups apart Ahl Sunnah is known as Ahl awah (people of self-desire), and they are called Ahl Bid 'ah (people of innovation) in tafsir literature. The political ideology motivated them to reject the Ahl Sunnah's exegesis. Meanwhile, they lost it all with many mistakes towards the interpretation of the Quran. Therefore their non-mainstream of tafsir is rejected by scholars of Tafsir and Islamic theologians. Among these groups that were counted during the formative phase of Tafsir are Shi'ah, al-Qadariyyah, and al-Murji'ah. Thus the exegetes among the companions is free of these sects, and they only made their existence reins in the mix of successor's exegetes. According to Ayoub Shi'tes beliefs that the Prophet is the only legit interpreter of the Quran then their master in their doctrine, any other scholars are not acceptable (Ayoub, 1948: 1189).

Notwithstanding, the Islamic sects (Firaq) have an impact in the evolution of tafsir, actually, the prayers of Muslim communities are continually answered. The notable books of tafsir that belong to authors from Ahl Sunnah are the blessings as far as all Islamic disciplines, including tafsir, are concerned. Distinctively, the most famous scholars of theology among Ahl Sunnah in this era are Abu Mansur al-Maturidi (d. 333/945) with the book Tawilat Ahl Sunnah, and Abu al-Layth al-Samarqandi (d. 373/984) his work is called Bahrul 'Ulum (as-Shamilah, 2021). They both emphasize many theological matters in their works. Repeatedly, they responded to any opinion that could instigate Ahl Sunnah's thought. For instance, the textual analysis of al-Maturidi will serve as clarification of this concept. During the interpretation of a verse in the Q2:255 in his work, 
he states: "And the Almighty said: (Who is he who intercedes with him except with his permission), the meaning: No one dares to intercede without his permission.

Therefore there are differences of opinions on intercession. The Mu'tazila said that intercession is only for people of good deeds, especially those who have not committed a sin, or they have sinned, so they repented totally. They based their evidence on the word of Allah: (The angels: who hold the throne and those around it, they are praising their Lord by thanksgiving and also believe in Him, and ask forgiveness for those believers. O Lord and seek all mercy and note forgive those who repent, follow your path, and save them from the torment of hell), (Mu'tazila continues); in this verse, it was told that they would ask for forgiveness for those who believe and repent and follow. Then If the forgiveness in this world is only for those who believe, repent, and follow, for that intercession is only for those believers in the hereafter. Direct reply from Abu Mansur: As for us (Ahl Sunnah): the mediation is also for people of sins. Because he who does not sin has no need to seek intercession. So Allah's word: (For those who repent and follow your path), they have sinned in conditions of repentance, but they are forgiven for their sins, so forgiveness appeared to the people of sins. This is the extraordinary situation of the intercession. The exegete added that if someone said to us: all of what was mentioned in this verse from the beginning to the end is all a claim, and then what is the evidence for that claim? In response, firstly: The proof of this may be the verse mentioned earlier: In the creation of the heavens and earth, and the divergence of the night and the day (al-Maturidi, 2005: 236-237).

Secondly, He who denies the maker, first they will talk with him about the event of the world and his need for a creator, and if the event of the world is proven, then they will speak about the proof of the maker and his oneness. Allah is the Grantor of success. As well, Almighty states: (Wahidun), not in terms of number; Because everything with a number may increase and decrease, and endure length and width, and tolerate shortening and breakage, but it is said: This is (one) attribute of Allah, is one in terms of greatness, majesty and elevation, as it is said: Somebody is one of his time, and one of his people, by which they mean his height and majesty in his people and his authority over them, it is permissible to say. They do not mean number; because many of them like him in terms of number. Allah knows better. This theological issue between Abu Mansur and Mu'tazila described the impact of intellectual occasions in the Quranic exegesis of this third century (al-Maturidi, 2005: 236-237).

Additionally, Hadith and jurisprudence as the branches of Islamic knowledge also reflect the evolution of tafsir at that period of time. At the same time, many famous jurists represented the noble tasks in the Quranic exegesis avenue with their jurisprudential exposure, such as Muhammad b. Idris ash-Shafi'i (d. 204/820), Even though he did not devote a book on interpretation of Quran, he was said. However, it has a significant influence on scholars in dealing 
with issues of tafsir. He revived the knowledge of the pilgrims, fixed the rules of inference, showed what could be called the tools needed for the interpreter, and deposited in his books especially what is in his ar-Risalah of that if it were collected and singled out and explained by its examples, it would have been of the most beneficial that for a student of exegesis studies. Ahmad b. Hambal said: (The jurists were doctors, and the modernists were pharmacists, so Muhammad bin Idris came as a pharmacist.) It likened him to the pharmacist who knows the types and grades of medicines and the doctor who knows the patient's illness and what works from the medication. Moreover it has been noted that al-Bayhaqi compiled a book for him on the Ahkam al-Qur'an, in which he combined in it what he narrated from al-Shafi'i regarding issues related to the rulings of the Qur'an. Ahmad b. Muhammad b. Hambal ash-Sheybani (d. 241/856), Ahmad is the great scholar of the Sunnis, Abu Ishaq al-Zujaj and Ibn al-Qayyim mentioned that Imam Ahmad had a book on exegesis, and Ibn al-Qayyim quoted from it in Badaa'i al-Fawa'id as brief religious matters, and if his tafsir was similar to what Ibn al-Qayyim, may God have mercy on him, reported, then it is a small part of the exegesis of the Qur'an. In the introduction to his tafsir, Ibn Taymiyyah said: (Likewise Imam Ahmad and others who were classified in tafsir repeat the paths on the authority of Mujahid more than others) (Jamharat al-Ulum, 2021).

Although al-Dhahabi denied that Ahmad had a major book on exegesis and was not famous for it, it was not narrated. Next in the list of jurists we have Ismail b. Ishaq b. Hammad b. Zayd alAzdi al-jahadami (d. 282/896) his work Ahakami al-Quran and Ma'ani al-Quran, Abu Bakr Muhammad b. Ibrahim b. al-Mundhir al-Nisaburi (d. 318/931). Abu al-Fadl Bakr bin Muhammed b. al-Ala al-Qushayri (d. 344/956), his book is Ahkam al-Qur'an, in which he summarized the rulings of the Qur'an by Judge Ismail bin Ishaq al-Maliki (d. 373/984), Abu Bakr Ahmed b. Ali AlJasas (d. 370/981) he has a printed book named Ahkam al-Qur'an, Muhammad b. Ali b. Ishaq ibn Khwiz Mandad al-Maliki (d. 390/1000), al-Dhahabi said: he has compiled many books, including: his big book al-Kilaf fi Usul al-Fikh, and his book Ahkam al-Qur'an.

Succinctly, contextual classification of jurisprudence rules is applied to jurist's exegesis. Base on the chapters of Islamic law and its topics, such as Fasting, Salat, purification, etc. Exactingly this is an exemplification of this claiming idea in the work of al-Jassa, in the area named; chapter on the permissibility of delaying the missing fast of Ramadan. He states that Almighty Allah said: (Whoever among you is ill or on travel, then several days later). He enjoins the waiting period on days that are not specified in the verse. So our scholars said: "It is permissible for him to fast any time he wants." There is no narration from them about the permissibility of delaying it until the end of the year. Jassas continues by saying; what I have is that it is not permissible to delay it until another Ramadan begins, and it is according to their beliefs, because if the matter for them is not temporary then the fast is to be replaced immediately (al-Jassas, 1994: 254) 
Meanwhile, the prophetic traditions and companions and their successors in tafsir must maintain the mainstream type of explanation. In this regard, we have the work of that great exegete Ibn Jarir al-Tabari (d. 310), as a sound and authentic example of mainstream tafsir's version, it combined the narrations from the life of the Prophet till the last part of the third century. Contextually work of Tabari Jami'al-Bayan an ta'wil ay al-Quran contributed to the evolution of Quranic exegesis in this period. He is moreover talking of Tafsir bil riwayah; which is the interpretation of the Quran based on the prophetic legacy and narrations from companions as well as the successors. In this work, Tabari had emphasized the exploitation of the Arabic language. He realized that understanding the grammatical structure is very important to an exegete. Tabari's obstinate belief matters by mentioning the views of scholars in Islamic sects such as Sunni, Ash'arites, Mu'tazila and Jabarites sect (Asyraf, at.all, 2017: 1818-5800). Although regarding the theological issue he seems to prefer Sunni's opinion. For instance, during his discussion on the word of Allah: "Then He turned to the heaven; He then proportioned them as seven heavens, and He is all-Knowing of everything" Q2:29. As stated above; in his interpretation of this verse, he mentions the opinions and then chooses the concept of Ahl sunnah that the word Istawa' in Arabic has many meanings. While in verse it means the highness of Allah and His Superior power on His creature the heavens. Lastly, to recover the sound knowledge of tafsir in the academic lines, above is the sample of the works of the exegetes. Significantly travails are worthy of being rendered towards the interpretation of the Qur'an for the sake of appropriate expression.

\section{Conclusion}

The Quran is a noble revelation, it was revealed to Prophet Muhammad as guidance for humankind. Therefore, Quranic exegesis is a mandatory task upon the Prophet, Allah (saw) commanded him to explain this world message during his lifetime. Certainly, the tafsir achieved its virtue from the Quran, so the development of tafsir began with the Islamic religion. However, the companions grasp the Qur'anic exegesis by memorizing its words and understanding its textual meanings. Moreover, the second generation is thought of by the companions. The tafsir gained independence as a separate discipline from the science of Hadith during the successor's era. Afterward, the Muslim nation is expanded, in the third century of Islam, many embraced Islam, scholars observed how much the Muslims needed the contextual expression to the Quran. In this regard, many scholars offered their Quranic exegesis by their various sections of Islamic knowledge with authentic narrations from the previous generation. Subsequently, the Quranic exegesis derives excellent development in these periods; the first three centuries must not be forgotten to any genuine Muslim and should be kept historically for the upcoming generation. 


\section{References}

Abdul-Raof, Hussein. School of Qur'anic Exegesis: Genesis and Development. London and New York: Roulage, 2010

Abbott Nabia, Tefsir'in Erken Dönem Gelişimi, tr. Mehmet Akif KOÇ, AÜİFD v. XUII no. 2 (2002): 449-462.

Abu al-Hassan, Maqatil bn Sulaiman bn Bashir al-Azdi al-Balkhi. d. 150H. Tafsir Makatil bn Sulaiman. ed. 'Abdullah Mahmud Shuhatih. 1st ed. Bairut: Daru Ihya al-Tutath, 2002.

As-San'ani, Abu Bakr 'Abdulrrazaq bn Hammam. d. 211H. Tafsir 'Abdulrrazaq. ed. Mahmud Muhammad 'Abduh. 1st ed. Bairut: Darul'Kutub al-'Ilmiyyah, 1998.

Asyraf Hj Ab Rahman, Firdaus Khairi Abdul Kadir, and others. The development of Tafsir from the Prophet Muhammad Down to Ibn Kathir. The Social Sciences, Center for fundamental and liberal Education, Universiti Malaysia Trengganu, medwell journals, 12 (2) (2017)

Ayoub, M. Muhmoud. The Quran and Its Interpreters. New York: Suny Press, Albany, 1948.

Cerrahoglu, Ismail. Tafsir Tarihi. Mizanul-Hak İslamer Dergi Ankara: frcr Yayınları, 2015.

Doğan, Mehmet Zeki-Güneş Abdülbaki. A Brief Overview to The Historyof Tafsiri. İlahiyat, 2019.

Az-Zujaj, Abu Ishaq Ibrahim bn as-Sirri bn Sahl. d. 310H. Ma'ani al-Qur'an wa I'irabuhu. ed. 'Abdul'Jalil 'Abduh al-Shelbi. 1st ed. Bairut: 'Alamul' Kutub, 1988.

al-Farra', Abu zakariya Yahaya b. Ziyad. d.207H. Ma'ani al-Quran,Cairo: (Daru al-Misriyah Lita'lif wa at-Tarjamah, 2014.

Al-Harwi al-Bagdadi, Abu 'Ubaid al-Qasim bn Sallam bn 'Abdullah. d. 224H. ed. Muhammad bn Salih al-Madifar. 2nd ed. Riyad: Maktabatul’Rushid/Sharkatul'Riyad, 1997.

Al-Ifriqi al-Qayrawani, Yahaya bn Sallam. Tafsir Yahya bn Sallam. d. 200H. ed. Hind Shalbi. 1st ed. Bairut: Darul'Kutub al-'Ilmiyyah, 2004.

Ibn 'Ashûr, Muhammad Tahir b. Muhammad b. Muhammad. d.1393H. at-Tahrir wa at-Tanwir, Tunis: Daru at-Tunisiyah li Nashr, 1984

Ibn Kathir, Ismail b. 'umar b. Katheer. d.774H. Tasir al-Qur'an al-Azim. ed. Sami b. Muhammad Salāmat, Dāru t-Tayba li Nashr wa Tawzi': Riyād, 1999.

Ibn Jma'ah, Muhammad. at-Tatawwur at-Tarikhi li Harakat t-Tafsir. Multaka Ahl Tafsir. Multaka Ahl Tafsir. July 16, 2010. https://vb.tafsir.net/forum (Accessed January 08, 2021).

al-jalal as-suyuti, Abdul Rahman bin Abubakir bin Muhammad. d.911H, "Al-itqon fii ulum AlQur'an", ed. Hamid Ahmad At-tair Al-basyuni, 2nd ed. Cairo: Dārul Fajir Lil turāth, 2010.

al-Jassas, Ahmad b. Ali Abubakr ar-Razi . d.370H. Ahkam al-Quran, ed. 'Abduls-Salam Muhammad Ali Shayn , 1st ed. Beirut: Darul-Kutub al-'Ilmiyah, 1994.

Khanam, Farida. A Simple Guide to Islam.2001, Islamic bookstore.com. https://www.islamicbookstore.com/b8320.html (Accessed December 30, 2020).

al-Mahali, Muhammad b. Ahmad. d.864H, as-Suyuti, Jalaldin Abdulrahman b. Abi Bakr. d.911H. Tafsir al-Jalalayn. 1st ed. Cairo: Darul Hadith, 2001.

al-Maturidi, Muhammad b. Muhammad b. Muhammad Abu Mansur. d.333H. Tawilat Ahl Sunnah , ed. Majidi Baslum, 1st ed. Beirut: Darul-Kutub al-'Ilmiyah, 2005. 
al-Mutayri, 'Abdul Aziz b. Dakhil, Tarikh Tadwin al-Tafsir, Jamharat al-Ulum, Muntada Jamharat al-Ulum (AccessedJanuary 09, 2021). https://jamharah.net/showthread.php?t=28080.

al-Qurtabi, Abu Abdullah Muhammad b. Ahmad b. Abi Bakr al-Ansāri al-Khaziraji. d.671H. al-Jamiu li Ahkāmi al-Qur'an. ed. Ahmad al-Barduni, Ibrahim Atfish, 2nd ed. Cairo: Dāru al-Kutub alMisriyah, 1997.

Recep Dogan, Usul Al-Tafsir: The Sciences and Methodology of Qur'ān (New Jersey: Tughra Books, 2014.

Sha'fi, Abu 'Abdullah Muhammad bn Idris bn 'Uthman bn Sha'fi bn 'Abdul'Mutalib bn 'Abd-Manaf al-Mutalibi al-Qurashi al-Makki. d. 204H. Tafsir al-Imam As-Shafi. ed. Ahmad bn Mustapha al- Farrani, 1st ed. Saudi: Daru at-Tadmiriyyah, 2006.

as-Shamilah. Kutub at-Tafasir. al-Maktabat as-Shamilah, January 09, 2021. https://almaktaba.org/category/127.

al-Tabari, Muhammad ibn Jarir. d.310H. Jāmi` al-bayān 'an ta’wīl āy al-Qur’ān. ed. Hāni al-Hāj, 'Amād Zeky al- Bārudy, Khayry Sa' heed, 3rd ed. Cairo: Dāru Tawfiqiyah li Tibā'a, 2013.

Al-Thawri, Abu 'Abdullah Sufyah bn Sai'd bn Masruq al-Kufi. d. 161H. Tafsir Sufyan al-Thawri. Bairut: Darul'Kutub al-'Ilmiyyah, 1983.

Von Denffer, Ahmad. Ulum al Qur'an: an introduction to the sciences of the Qur'an. Kube Publishing Ltd, 2015.

Yasir Qadhi, Abu Ammaar. An Introduction to the Sciences of the Qur'aan. United Kingdom: AlHidaayah Publishing and Distribution, 1999. 